\title{
EFFECT OF ORGANIC FERTILIZATION AND PLANT SPACING ON THE GROWTH, OIL PRODUCTION AND ARTEMISININ CONTENT OF SWEET ANNIE (Artemisia aпnиa, L.)
}

(Received: 13.4.2011)

\author{
By \\ E.O. El-Ghawwas*, S. H. El-Hanafy, H.A. Mansour \\ and S. N. Abd El-khalek* \\ Ornamental Horticulture Department, Faculty of Agriculture, Cairo University. \\ * Medicinal and Aromatic Plants Research Department, Horticulture Research Institute, \\ Agricultural Research Center, Giza, Egypt.
}

\begin{abstract}
This study was carried out during the two successive seasons of 2008 and 2009, to investigate the response of Sweet Annie (Artemisia annua) to plant spacing $(60 \times 40,60 \times 60$ or $60 \times 80 \mathrm{~cm})$ and fertilization using poultry manure (PM) at the rates of 10,15 or $20 \mathrm{~m}^{3} / \mathrm{fed}$./season, or cattle manure (CM) at the rates of 15,25 or $35 \mathrm{~m}^{3} /$ fed./season. The results showed that the widest spacing $(60 \times 80 \mathrm{~cm})$ increased the mean fresh and dry herb yields/plant, as well as the oil percentage, oil yield/plant and artemisinin content in the leaves. The narrowest spacing $(60 \mathrm{x} 40 \mathrm{~cm})$ produced the highest fresh and dry herb yields/fed., and essential oil yield/fed. The application of PM at the rate of $20 \mathrm{~m}^{3} / \mathrm{fed}$. had the best effect on the mean fresh and dry herb yields (per plant and per fed.), as well as the oil percentage, oil yield per plant and artemisinin content in leaves. The combined treatment of $(60 \times 80 \mathrm{~cm})$ with PM fertilization at $15 \mathrm{~m}^{3} / \mathrm{fed}$., proved to be the best treatment combined for increasing the fresh and dry herb yields per plant, as well as the oil percentage, the oil yield/plant, and the content of artemisia keton (the main oil component). On the other hand, the highest fresh and dry herb yields/fed., as well as the highest oil yield/fed., were obtained from plants grown at the narrowest spacing $(60 \mathrm{x} 40 \mathrm{~cm})$, and fertilized with the highest $\mathrm{PM}$ rate $\left(20 \mathrm{~m}^{3} / \mathrm{fed}\right.$.).
\end{abstract}

Key words: Artemisia annua, artemisinin, fertilization, sweet annie.

\section{INTRODUCTION}

Medicinal and aromatic plants are important economic products, which are considered amongst the most important agricultural export products, and they represent significant sources of economic revenue and foreign currency. Egyptian environmental conditions are world-famous for being suitable for growing high quality medicinal and aromatic plants. Recently, there has been an increasing interest in the cultivation and production of medicinal plants in order to cover the growing demand by both local industries and international markets. The Asteraceae (Compositae) is one of the largest and most highly evolved plant families, with a world-wide distribution of about 2500 genera and 25000 species. The genus Artemisia includes about 200 species and some have been cultivated as commercial crops with a wide diversity of uses. Some better known examples include species with antimalarial activity (A. апnиа - annual or sweet wormwood, Sweet Annie), while others are used as culinary spices (A. dracunculus - French tarragon), garden ornamentals (A. abrotanum southernwood), insect repellents (A. vulgaris mugwort), or for liquor flavouring (A. absinthium - absinthe). However, this study will concentrate on the cultivation of $A$. апnиa because of its contemporary importance as a source of new and effective antimalarial drugs. Malaria kills a child every few seconds: most of the people who die from malaria are children not yet 5 years of age. Thus, control of this disease has now attained utmost attention, and if such a disease has an herbal solution, then it is surely a boon to mankind. Drug-resistant malaria is a major worldwide public health problem. In Southeast Asia, Plasmodium falciparum strains have become resistant to all of the classical antimalarial drugs. Fortunately, these strains are still susceptible to the artemisinin derivatives; derivatives such as artemether and artesunate are now widely used in 
this region. Artemisinin is a naturally occurring endoperoxide with anti-malarial properties, which has been used clinically as an anti-malaria drug. The range of artemisinin content of A. апnиa harvested from different production areas is wide. The highest content of artemisinin that can be reached in the leaves of $A$. annua is up to $1-2 \%$ (on a dry weight basis). Although the content of artemisinin is affected by numerous factors such as geographical conditions, harvesting time, temperature and fertilizer application. Harvesting at the appropriate time is critically important to ensure optimum content of artemisinin in $A$. апnиа, Zhong Guoyue (1998).

Medicinal and aromatic plants which are grown using organic and biofertilizers are more acceptable than those grown using chemical fertilizers, and are considered to be of higher quality. The demand for healthy organically produced crops (including medicinal plants) is increasingly spreading not only in Egypt but also all over the world. Fertilization using organic and biofertilizers not only provides plants with their nutritional requirements without having an undesirable impact on the environment, but also helps to increase and stabilize soil fertility, and improves the chemical and physical characteristics of the soil.

Plant spacing is an important agronomic factor which affects plant growth and productivity through light interception during photosynthesis. Also, plant spacing has a considerable impact on the exploitation of the photosphere and rhizosphere by the plants, especially when spacing is inadequate, and the plants suffer clustering together. Good plant spacing gives the right plant density, which is the number of plants allowed on a given area of land for optimum yield (Obi, 1991).

\section{MATERIALS AND METHODS}

This study was conducted at the farm of the Medicinal and Aromatic Plants Research Department (located in El-Kanater El-Khaireya, Kalyoubeya Governorate), Horticulture Research Institute, Agricultural Research Center, Dokki, Giza, during the two successive seasons of 2008 and 2009. The aim of the study was to investigate the effect of some organic fertilizers (poultry and cattle manures) and plant spacing on the growth, oil yield, and artemisinin content of Sweet Annie (Artemisia anпиа L.).

Artemisia annua seeds were sown on the $20^{\text {th }}$ of February in a peat moss medium in the nursery beds, where they germinated within 10-15 days. Two months after sowing the seeds (on the $20^{\text {th }}$ of April, 2008 and 2009 in the two seasons, respectively), when the seedlings were $15-20 \mathrm{~cm}$ in height, were transplanted to plots in the open field. The area of each plot was $2.5 \times 3 \mathrm{~m}$ containing three rows $60 \mathrm{~cm}$ apart and 2.75 meters in length. The chemical analysis of the soil of the experimental field showed that it contained 26.2 ppm N, 106 ppm $\mathrm{P}_{2} \mathrm{O}_{5}, 178$ ppm $\mathrm{K}_{2} \mathrm{O}, 5.22 \mathrm{ppm}$ $\mathrm{Zn}, 2.77 \mathrm{ppm} \mathrm{Fe}, 2.38 \mathrm{ppm} \mathrm{B}, 0.66 \mathrm{ppm} \mathrm{Mn}$, and $0.43 \mathrm{ppm} \mathrm{Cu}$.

The seedlings were planted on the rows at three different spacings, viz. 40,60 or $80 \mathrm{~cm}$. Plants grown at each of the three spacings were fertilized using different poultry manure (PM) and cattle manure $(\mathrm{CM})$ application rates. Poultry manure was applied at the rates of 10,15 and $20 \mathrm{~m}^{3} / \mathrm{fed}$.,

Table (1): Physical and chemical characteristics of the organic manures used for fertilization of Sweet Annie (Artemisia аппиа L.) plants during the 2008 and 2009 seasons.

\begin{tabular}{|l|c|c|c|c|}
\hline \multirow{2}{*}{ Organic manure characteristics } & \multicolumn{2}{|c|}{ Poultry manure (PM) } & \multicolumn{2}{c|}{ Cattle manure (CM) } \\
\cline { 2 - 5 } & $\mathbf{1}^{\text {st }}$ season & $\mathbf{2}^{\text {nd }}$ season & $\mathbf{1}^{\text {st }}$ season & $\mathbf{2}^{\text {nd }}$ season \\
\hline Weight of $1 \mathrm{~m}^{3}(\mathrm{~kg})$ & 691 & 546 & 478 & 468 \\
\hline Moisture content (\%) & 7.30 & 9.33 & 10.03 & 9.00 \\
\hline Organic matter (\%) & 64.21 & 82.17 & 59.87 & 60.24 \\
\hline Organic carbon (\%) & 39.32 & 51.30 & 30.79 & 36.27 \\
\hline Total N (\%) & 2.28 & 3.50 & 1.78 & 1.73 \\
\hline $\mathrm{C}: \mathrm{N} \mathrm{ratio}$ & $15.2: 1$ & $13.0: 1$ & $17.2: 1$ & $17.7: 1$ \\
\hline $\mathrm{NH}_{3}-\mathrm{N}(\mathrm{ppm})$ & 2928.8 & 3148.9 & 44.3 & 64.6 \\
\hline $\mathrm{NO}_{3}-\mathrm{N}(\mathrm{ppm})$ & 170.8 & 214.6 & 170.4 & 208.8 \\
\hline Total P $(\%)$ & 1.05 & 0.70 & 0.30 & 0.64 \\
\hline Total K $(\%)$ & 0.74 & 1.78 & 1.03 & 1.13 \\
\hline $\mathrm{Fe}(\mathrm{ppm})$ & 1.689 & 1.624 & 1.789 & 1.590 \\
\hline $\mathrm{Mn}(\mathrm{ppm})$ & 120.3 & 158.3 & 180.5 & 189.9 \\
\hline $\mathrm{Zn}(\mathrm{ppm})$ & 81.50 & 81.90 & 91.42 & 97.9 \\
\hline $\mathrm{Cu}(\mathrm{ppm})$ & 33.7 & 50.4 & 39.4 & 43.4 \\
\hline
\end{tabular}


while $\mathrm{CM}$ was applied at rates of 15,25 and 35 $\mathrm{m}^{3} /$ fed. The poultry and the cattle manures were obtained from the Animal Production Department, El-Kanater El-Khaireya, Agricultural Research Center. The physical and chemical characteristics of the two types of manure are presented in Table (1). The organic fertilization treatments were applied by incorporating the different PM and CM rates into the soil two weeks before transplanting the seedlings (on 5 April 2008 and 2009 in the two seasons, respectively).

This experiment was designed using a factorial split plot design, with 21 treatment combinations (3) plant spacing treatments $\mathrm{x} 7$ organic fertilization treatments, including the control). The organic fertilization treatments were assigned as the main plots in a randomized complete block design with three blocks (replicates), while the plant spacing treatments were assigned as the subplots.

All plants received common agricultural practices, including regular watering and manual removal of weeds. At the end of each growing season, the plants were harvested at early bloom stage (on the $20^{\text {th }}$ of October 2008 and 2009 in the two seasons, respectively) by cutting the vegetative parts $10-15 \mathrm{~cm}$ above the soil surface.

In each season, data were recorded on herb fresh weight/plant $(\mathrm{g})$, while herb dry weight/plant (g) was recorded after air-drying in a sunny area. The fresh and dry herb yields/fed. (ton) were calculated by multiplying the herb fresh and dry weights/plant, respectively, by the number of plants/fed. Also, the oil percentage in the dry herb was determined using the method described by the British Pharmacopoeia (1963) by hydro distillation of $100 \mathrm{~g}$ of dry herb for 4.0 hours. The essential oil yield per plant was calculated in proportion to the herb dry weight/plant. The main constituents of Sweet Annie essential oil were determined by subjecting oil samples (taken from the oil obtained in the first season) to gas liquid chromatographic (GLC) analysis, as recommended by Simon and Quinn (1988). Also, dry leaf samples were chemically analyzed to determine their artemisinin content using the method outlined by Peng et al. (2006), by which $95-98 \%$ of the artemsinin in the leaves can be extracted.

An analysis of variance (ANOVA) was conducted on the data recorded on fresh and dry herb yields per plant and per fed. The means were compared using the "Least Significant Difference (L.S.D)" test at the $5 \%$ level, as described by Little and Hills (1978).

\section{RESULTS AND DISCUSSION \\ 3.1.Vegetative growth \\ 3.1.1. Herb fresh and dry weights/plant}

The results presented in Tables (2) and (3) show that in both seasons, the highest herb fresh and dry weights per plant were obtained with the widest spacing $(60 \times 80 \mathrm{~cm})$. The increase in the fresh and dry weight / plant as a result of wide spacing may be attributed to the low density of the plants, allowing the formation of a strong root system, and resulting in a greater uptake of soil, water and nutrients. Also, the wide spacing between the shoots allowed the leaves to capture enough sunlight and air, thus enhancing photosynthesis and metabolic activity, which are subsequently converted into more vegetative growth, resulting in high fresh weights. These results are in harmony with those reported by ElShaer (1989) on Foeniculum vulgare and ElGendy et al. (2001 a) on Ocimum basilicum.

The data in Tables (2 and 3) also show that organic fertilization using poultry manure (PM) and cattle manure $(\mathrm{CM})$ had a significant effect on the fresh and dry weights/plant. In both seasons, it is clear that the application of the different organic fertilizer treatments led to significant increases in the herb fresh and dry weights compared to the control. Poultry manure (PM) was clearly more effective than $\mathrm{CM}$ in this regard. Also, the recorded values showed steady significant increases as the fertilization rate was raised. Accordingly, the highest herb fresh and dry weights were those of plants fertilized using the highest PM rate $\left(20 \mathrm{~m}^{3} /\right.$ fed.). The superior effect of PM on fresh and dry weight / plant may be attributed to the higher $\mathrm{N}$ content of PM, compared to that of $\mathrm{CM}$, as shown by the results of the chemical analysis of the two organic fertilizers (Table 1). The advantages of using PM (compared to other organic fertilizers) were also detected by El-Ghadban (1998) on Mentha viridis and Hassan (2008) on Thymus vulgaris.

Regarding the interaction between the effects of plant spacing and organic fertilization on herb fresh and dry weights / plant, the data presented in Tables (1\&2) show that significant differences were recorded between the fresh and dry weights of plants receiving the various combinations of these two factors. In both seasons, the heaviest herb fresh and dry weights/plants were those of plants grown at the widest spacing $(80 \mathrm{~cm})$ and supplied with PM at the rate of $15 \mathrm{~m}^{3} /$ fed.

\subsection{Fresh and dry herb yields/fed.}

The results recorded in the two seasons (Tables 4 and 5) show that the highest mean fresh and dry 
Table (2): Effect of spacing and organic fertilization treatments on herb fresh weight/plant (g) of Artemisia annua in 2008 and 2009 seasons.

\begin{tabular}{|c|c|c|c|c|c|c|c|c|}
\hline \multirow{3}{*}{$\begin{array}{c}\text { Plant spacing } \\
\text { (S) }\end{array}$} & \multicolumn{7}{|c|}{ Herb fresh weight / plant (g) } & \multirow{3}{*}{$\begin{array}{c}\text { Means } \\
\text { (S) }\end{array}$} \\
\hline & \multicolumn{7}{|c|}{ Fertilization treatments $(\mathbf{F})^{*}$} & \\
\hline & Control & PM1 & PM2 & PM3 & CM1 & CM2 & CM3 & \\
\hline & \multicolumn{8}{|c|}{ First season (2008) } \\
\hline $60 \times 40 \mathrm{~cm}$ & 560.67 & 1325.00 & 1658.33 & 1833.33 & 933.33 & 1080.00 & 1333.33 & 1246.29 \\
\hline $60 \times 60 \mathrm{~cm}$ & 433.33 & 780.00 & 1216.67 & 1681.67 & 648.33 & 846.67 & 1020.00 & 946.67 \\
\hline $60 \times 80 \mathrm{~cm}$ & 946.67 & 1856.67 & 2571.67 & 2150.00 & 1173.33 & 1488.33 & 1628.33 & 1687.86 \\
\hline Means (F) & 646.89 & 1320.56 & 1815.56 & 1888.33 & 918.33 & 1138.33 & 1327.22 & -- \\
\hline \multicolumn{9}{|l|}{ LSD (0.05) } \\
\hline $\mathbf{S}$ & \multicolumn{8}{|c|}{48.10} \\
\hline $\mathbf{F}$ & \multicolumn{8}{|c|}{44.56} \\
\hline \multirow[t]{2}{*}{$\mathbf{S ~ X ~ F ~}$} & \multicolumn{8}{|c|}{40.43} \\
\hline & \multicolumn{8}{|c|}{ Second season (2009) } \\
\hline $60 \times 40 \mathrm{~cm}$ & 558.33 & 1325.00 & 1663.33 & 1845.33 & 930.00 & 1080.00 & 1336.67 & 1248.38 \\
\hline $60 \times 60 \mathrm{~cm}$ & 451.67 & 770.00 & 1227.67 & 1653.33 & 660.00 & $\mathbf{8 7 3 . 3 3}$ & 1033.33 & 952.76 \\
\hline $60 \times 80 \mathrm{~cm}$ & 948.33 & 1843.33 & 2576.67 & 2260.00 & 1180.00 & 1491.67 & 1650.00 & 1707.14 \\
\hline Means (F) & 652.77 & 1312.78 & 1822.56 & 1919.56 & 923.33 & 1148.33 & 1340.00 & -- \\
\hline \multicolumn{9}{|l|}{ LSD (0.05) } \\
\hline $\mathbf{S}$ & \multicolumn{8}{|c|}{41.60} \\
\hline $\mathbf{F}$ & \multicolumn{8}{|c|}{35.00} \\
\hline $\mathbf{S} \mathbf{X} \mathbf{F}$ & \multicolumn{8}{|c|}{24.07} \\
\hline
\end{tabular}

* PM1, PM2 and PM3 = Poultry manure at 10, 15 and $20 \mathrm{m3} /$ fed., respectively.

CM1, CM2 and CM3 = Cattle manure at 15, 25 and $35 \mathrm{m3}$ / fed., respectively. 
Table (3): Effect of spacing and organic fertilization treatments on dry weight / plant (g) of Artemisia апnиa in 2008 and 2009 seasons.

\begin{tabular}{|c|c|c|c|c|c|c|c|c|}
\hline \multirow{3}{*}{$\begin{array}{c}\text { Plant } \\
\text { spacing } \\
\text { (S) }\end{array}$} & \multicolumn{7}{|c|}{ Dry weight / plant (g) } & \multirow{3}{*}{$\begin{array}{c}\text { Means } \\
\text { (S) }\end{array}$} \\
\hline & \multicolumn{7}{|c|}{ Fertilization treatments $(\mathbf{F})^{*}$} & \\
\hline & Control & PM1 & PM2 & PM3 & CM1 & CM2 & CM3 & \\
\hline & \multicolumn{8}{|c|}{ First season (2008) } \\
\hline $60 \times 40 \mathrm{~cm}$ & 352.33 & 968.97 & 1093.00 & 1156.73 & 592.20 & 671.97 & 852.27 & 812.49 \\
\hline $60 \times 60 \mathrm{~cm}$ & 308.11 & $\mathbf{5 5 9 . 5 3}$ & 862.33 & 1231.63 & 454.77 & 639.23 & 717.83 & 681.92 \\
\hline $60 \times 80 \mathrm{~cm}$ & 535.36 & 1092.87 & 1560.33 & 1307.93 & 706.33 & 912.40 & 1025.27 & 1020.07 \\
\hline Means (F) & 398.60 & 873.79 & 1171.89 & 1232.10 & 584.43 & 741.20 & 865.12 & --- \\
\hline \multicolumn{9}{|l|}{ LSD (0.05) } \\
\hline $\mathbf{S}$ & \multicolumn{8}{|c|}{35.72} \\
\hline $\mathbf{F}$ & \multicolumn{8}{|c|}{31.29} \\
\hline \multirow[t]{2}{*}{ S X F } & \multicolumn{8}{|c|}{29.95} \\
\hline & \multicolumn{8}{|c|}{ Second season (2009) } \\
\hline $60 \times 40 \mathrm{~cm}$ & 343.33 & 967.67 & 1093.00 & 1161.67 & 588.17 & 673.00 & 851.27 & 811.16 \\
\hline $60 \times 60 \mathrm{~cm}$ & 314.33 & 560.00 & 863.67 & 1212.00 & 466.67 & 655.47 & 713.10 & 683.60 \\
\hline $60 \times 80 \mathrm{~cm}$ & 540.00 & 1096.67 & 1564.67 & 1310.33 & 723.90 & 899.27 & 1028.40 & 1023.32 \\
\hline Means (F) & 399.22 & 874.78 & 1173.78 & 1228.00 & 592.91 & 742.58 & 864.25 & --- \\
\hline \multicolumn{9}{|l|}{ LSD (0.05) } \\
\hline $\mathbf{S}$ & \multicolumn{8}{|c|}{22.66} \\
\hline $\mathbf{F}$ & \multicolumn{8}{|c|}{34.34} \\
\hline $\mathbf{S X} \mathbf{F}$ & \multicolumn{8}{|c|}{20.33} \\
\hline
\end{tabular}

* PM1, PM2 and PM3 = Poultry manure at 10, 15 and $20 \mathrm{m3}$ / fed., respectively. CM1, CM2 and CM3 = Cattle manure at 15, 25 and $35 \mathrm{m3} /$ fed., respectively. 
Table (4): Effect of spacing and organic fertilization treatments on the fresh herb yield/feddan (ton) of Artemisia annua in 2008 and 2009 seasons.

\begin{tabular}{|c|c|c|c|c|c|c|c|c|}
\hline \multirow{3}{*}{$\begin{array}{c}\text { Plant } \\
\text { spacing } \\
\text { (S) }\end{array}$} & \multicolumn{7}{|c|}{ Fresh herb yield / feddan (ton) } & \multirow{3}{*}{$\begin{array}{c}\text { Means } \\
\text { (S) }\end{array}$} \\
\hline & \multicolumn{7}{|c|}{ Fertilization treatments $(\mathbf{F})^{*}$} & \\
\hline & Control & PM1 & PM2 & PM3 & CM1 & CM2 & CM3 & \\
\hline & \multicolumn{8}{|c|}{ First season (2008) } \\
\hline $60 \times 40 \mathrm{~cm}$ & 9.34 & 22.08 & 27.63 & 30.55 & 15.55 & 17.99 & 22.22 & 2.77 \\
\hline $60 \times 60 \mathrm{~cm}$ & 4.81 & 8.66 & 13.51 & 18.65 & 7.20 & 9.40 & 11.33 & 10.51 \\
\hline $60 \times 80 \mathrm{~cm}$ & 7.88 & 15.47 & 21.42 & 13.77 & 9.77 & 12.40 & 13.56 & 13.47 \\
\hline Means (F) & 7.34 & 15.40 & 2.086 & 21.00 & 10.84 & 13.26 & 15.70 & --- \\
\hline \multicolumn{9}{|l|}{ LSD (0.05) } \\
\hline $\mathbf{S}$ & \multicolumn{8}{|c|}{3.56} \\
\hline $\mathbf{F}$ & \multicolumn{8}{|c|}{4.40} \\
\hline \multirow[t]{2}{*}{$\mathbf{S X} \mathbf{F}$} & \multicolumn{8}{|c|}{5.18} \\
\hline & \multicolumn{8}{|c|}{ Second season (2009) } \\
\hline $60 \times 40 \mathrm{~cm}$ & 9.30 & 22.08 & 27.72 & 30.75 & 15.49 & 17.99 & 22.27 & 20.80 \\
\hline $60 \times 60 \mathrm{~cm}$ & 5.01 & 8.95 & 13.95 & 18.87 & 7.63 & 9.90 & 11.98 & 10.90 \\
\hline $60 \times 80 \mathrm{~cm}$ & 7.90 & 15.16 & 21.27 & 18.63 & 9.63 & 12.23 & 13.54 & 14.05 \\
\hline Means (F) & 7.40 & 15.39 & 20.98 & 22.75 & 10.92 & 13.37 & 15.93 & -- \\
\hline \multicolumn{9}{|l|}{ LSD (0.05) } \\
\hline $\mathbf{S}$ & \multicolumn{8}{|c|}{3.21} \\
\hline $\mathbf{F}$ & \multicolumn{8}{|c|}{4.36} \\
\hline $\mathbf{S X} \mathbf{F}$ & \multicolumn{8}{|c|}{4.96} \\
\hline
\end{tabular}

* PM1, PM2 and PM3 = Poultry manure at 10,15 and $20 \mathrm{m3} /$ fed., respectively.

CM1, CM2 and CM3 = Cattle manure at 15,25 and $35 \mathrm{~m} 3$ / fed., respectively. 
Table (5): Effect of spacing and organic fertilization treatments on the dry herb yield / feddan (ton) of Artemisia annua in 2008 and 2009 seasons.

\begin{tabular}{|c|c|c|c|c|c|c|c|c|}
\hline \multirow{3}{*}{$\begin{array}{c}\text { Plant spacing } \\
\text { (S) }\end{array}$} & \multicolumn{7}{|c|}{ Dry herb yield / feddan (ton) } & \multirow{3}{*}{$\begin{array}{c}\text { Means } \\
\text { (S) }\end{array}$} \\
\hline & \multicolumn{7}{|c|}{ Fertilization treatments $(\mathbf{F})^{*}$} & \\
\hline & Control & PM1 & PM2 & PM3 & CM1 & CM2 & CM3 & \\
\hline & \multicolumn{8}{|c|}{ First season (2008) } \\
\hline $60 \times 40 \mathrm{~cm}$ & 5.87 & 16.15 & 18.21 & 19.28 & 9.87 & 11.20 & 14.20 & 13.43 \\
\hline $60 \times 60 \mathrm{~cm}$ & 3.42 & 6.22 & 9.58 & 13.68 & 5.05 & 7.10 & 7.975 & 7.58 \\
\hline $60 \times 80 \mathrm{~cm}$ & 4.46 & 9.11 & 13.00 & 10.90 & 5.89 & 7.60 & 8.54 & 8.50 \\
\hline Means (F) & 4.58 & 10.49 & 13.59 & 14.62 & 6.93 & 8.63 & 10.24 & --- \\
\hline \multicolumn{9}{|l|}{ LSD (0.05) } \\
\hline $\mathbf{S}$ & \multicolumn{8}{|c|}{2.14} \\
\hline $\mathbf{F}$ & \multicolumn{8}{|c|}{3.10} \\
\hline $\mathbf{S} \times \mathbf{F}$ & \multicolumn{8}{|c|}{4.12} \\
\hline & \multicolumn{8}{|c|}{ Second season (2009) } \\
\hline $60 \times 40 \mathrm{~cm}$ & 5.72 & 16.13 & 18.21 & 19.38 & 9.80 & 11.22 & 14.19 & 13.52 \\
\hline $60 \times 60 \mathrm{~cm}$ & 3.49 & 6.22 & 9.60 & 13.47 & 5.19 & 7.28 & 7.92 & 7.59 \\
\hline $60 \times 80 \mathrm{~cm}$ & 4.50 & 9.14 & 13.03 & 10.91 & 6.03 & 7.49 & 8.57 & 8.52 \\
\hline Means (F) & 4.57 & 10.49 & 13.61 & 14.58 & 7.00 & 8.66 & 10.22 & --- \\
\hline \multicolumn{9}{|l|}{ LSD (0.05) } \\
\hline $\mathbf{S}$ & \multicolumn{8}{|c|}{2.17} \\
\hline $\mathbf{F}$ & \multicolumn{8}{|c|}{2.00} \\
\hline $\mathbf{S X F}$ & \multicolumn{8}{|c|}{1.98} \\
\hline
\end{tabular}

* PM1, PM2 and PM3 = Poultry manure at 10,15 and $20 \mathrm{~m} 3$ / fed., respectively. CM1, CM2 and CM3 = Cattle manure at 15, 25 and $35 \mathrm{m3} /$ fed., respectively. 
herb yields/fed were produced as a result of growing the plants at the narrowest spacing $(60 \mathrm{x}$ $40 \mathrm{~cm}$ ). This was due to the high plant density at this spacing. These conclusions are in agreement with the findings of Badi et al. (2004) on Thymus vulgaris.

It can also be seen from the data presented in Tables (4) and (5) that the two highest PM application rates (15 or $20 \mathrm{~m}^{3} / \mathrm{fed}$.) were the most effective fertilization treatments, giving the highest mean fresh and dry herb yields/fed. (in both seasons), with no significant difference between the values obtained with these two application rates. The advantages of using PM (compared to other organic fertilizers) were also detected by Mohsen (2002) on Ocimum basilicum cv. Grand Vert, and Vieira et al. (2002) on Mentha villosa and Mentha longifolia.

Regarding the interaction between plant spacing and organic fertilization, it can be seen that in both seasons, the best treatment combination (i.e., giving the highest fresh and dry herb yields/fed.) was using a plant spacing of $60 \mathrm{x}$ $40 \mathrm{~cm}$, with organic fertilization PM at $20 \mathrm{~m}^{3}$.

\subsection{Essential oil production}

\subsubsection{Essential oil percentage}

The synthesis and accumulation of the essential oil in Sweet Annie plants were clearly enhanced by the wide spacing (Table 6). In both seasons, plants grown at the widest spacing $(60 \mathrm{x}$ $80 \mathrm{~cm}$ ) had a significantly higher mean oil percentage, compared to plants grown at the narrowest $(60 \times 40 \mathrm{~cm})$ and medium spacing $(60 \mathrm{x}$ $60 \mathrm{~cm})$. Similar increases in oil percentage as a result of wide plant spacing have been reported by Ahmed (1986) on Achillea millefolium, Refai et al. (1991) on Ruta graveolens, El-Tantawy et al. (1992) on Foeniculum vulgare Mill., and Morteza et al. (2010) on Valeriana officinalis L.

The results recorded in the two seasons (Table 6) also show that PM was generally more effective than $\mathrm{CM}$ in increasing the essential oil percentage, especially when it was applied at the high rates ( 15 or $20 \mathrm{~m}^{3} / \mathrm{fed}$.). The increase in the essential oil content of plants fertilized with PM, compared to the control and plants fertilized with $\mathrm{CM}$, is in agreement with the results obtained by Jacoub (1999) and Mohsen (2002) on Ocimum basilicum, Salim (2006) on Salvia officinalis, and Hassan (2008) on Thymus vulgaris.

It is also evident from the results in Table (6) that the interaction between the effects of plant spacing and organic fertilization (using PM and $\mathrm{CM}$ ) on the oil content in the dry herb was significant. In both seasons, the plants grown at the widest spacing $(60 \times 80 \mathrm{~cm})$ and fertilized with $\mathrm{PM}$ at $20 \mathrm{~m}^{3} / \mathrm{fed}$. had the highest oil percentage.

\subsubsection{Essential oil yield/plant}

As previously mentioned, planting at the widest spacing $(60 \times 80 \mathrm{~cm})$ increased the herb fresh and dry weights/plant, as well as the synthesis and accumulation of the essential oil (i.e. the oil percentage). Consequently, the results presented in Table (7) show that in both seasons, plants grown at a spacing of $60 \times 80 \mathrm{~cm}$ gave a higher essential oil yield/plant, compared to the plants grown at $60 \times 60 \mathrm{~cm}$ or $60 \times 40 \mathrm{~cm}$. Similar increases in essential oil yield/plant as a result of wide plant spacing have been reported by Ahmed (1986) on Achillea millefolium and Ahmed (1997) on Nigella sativa.

The results recorded in the two seasons (Table 7) also show that PM fertilization at the rates of 15 or $20 \mathrm{~m}^{3} / \mathrm{fed}$. increased the oil yield/plant, compared to the values obtained from the control plants, or from plants receiving CM fertilization. These results are in agreement with the findings of Jacoub (1999) and Mohsen (2002) on Ocimum basilicum L. cv."Grand Vert", and Hassan (2008) on Thymus vulgaris.

Regarding the interaction between the effects of plant spacing and organic fertilization on the oil yield/plant, the data in Table (7) show that the highest oil yield/plant was obtained from plants grown at the widest spacing $(60 \times 70 \mathrm{~cm})$ and supplied with the medium PM rate $\left(15 \mathrm{~m}^{3} / \mathrm{fed}\right)$.

\subsection{Essential oil yield/fed.}

The essential oil yield/fed. was evidently more influenced by plant density (i.e., the number of plants/fed.) than by the essential oil yield/plant, or the herb weight/plant. Accordingly, Table (8) shows that growing the plants at the narrowest spacing $(60 \times 40 \mathrm{~cm})$, gave the highest number of plants/fed., also resulted in a significantly higher essential oil yield / fed., compared to values recorded with wider plant spacing $(60 \times 60 \mathrm{~cm}$, or $60 \times 80 \mathrm{~cm}$ ). Increases in the essential oil yield / fed. as a result of narrow plant spacing were also reported by Ahmed (1986) on Achillea millefolium, Kalyan et al. (1989) on Mentha arvensis, Shalaby and Razin (1992) on Thymus vulgaris, Shalaby et al. (1993) on Melissa officinalis, Ram et al. (1998) on Tagetes minuta and El-Gendy et al. (2001b) on Ocimum basilicum var. Grand Vert.

The results recorded in the two seasons (Table 8) also show that the different organic fertilization treatments increased the oil yield/fed. significantly, compared to the control. Fertilization using PM was most effective in 
Table (6): Effect of spacing and organic fertilization treatments on the essential oil content (\%) in the dry herb of Artemisia аппиа in 2008 and 2009 seasons.

\begin{tabular}{|c|c|c|c|c|c|c|c|c|}
\hline \multirow{3}{*}{$\begin{array}{c}\text { Plant } \\
\text { spacing } \\
\text { (S) }\end{array}$} & \multicolumn{7}{|c|}{ Essential oil content $(\%)$} & \multirow[t]{3}{*}{ Means } \\
\hline & \multicolumn{7}{|c|}{ Fertilization treatments $(\mathbf{F})^{*}$} & \\
\hline & Control & PM1 & PM2 & PM3 & CM1 & CM2 & CM3 & \\
\hline & \multicolumn{8}{|c|}{ First season (2008) } \\
\hline $60 \times 40 \mathrm{~cm}$ & 0.75 & 0.88 & 0.92 & 0.94 & 0.82 & 0.86 & 0.91 & 0.86 \\
\hline $60 \times 60 \mathrm{~cm}$ & 0.73 & 0.80 & 0.86 & 0.95 & 0.78 & 0.81 & $\mathbf{0 . 8 3}$ & 0.82 \\
\hline $60 \times 80 \mathrm{~cm}$ & 0.81 & 0.92 & 1.09 & 1.02 & 0.86 & 0.92 & 0.94 & 0.94 \\
\hline Means (F) & 0.76 & 0.86 & 0.96 & 0.97 & 0.82 & 0.86 & $\mathbf{0 . 8 9}$ & --- \\
\hline \multicolumn{9}{|l|}{ LSD (0.05) } \\
\hline $\mathbf{S}$ & \multicolumn{8}{|c|}{0.06} \\
\hline $\mathbf{F}$ & \multicolumn{8}{|c|}{0.04} \\
\hline \multirow[t]{2}{*}{$\mathbf{S} \times \mathbf{F}$} & \multicolumn{8}{|c|}{0.05} \\
\hline & \multicolumn{8}{|c|}{ Second season (2009) } \\
\hline $60 \times 40 \mathrm{~cm}$ & 0.78 & 0.89 & 0.94 & 1.01 & 0.85 & 0.91 & 0.92 & 0.89 \\
\hline $60 \times 60 \mathrm{~cm}$ & 0.76 & 0.81 & 0.88 & 0.97 & 0.82 & 0.84 & 0.86 & 0.85 \\
\hline $60 \times 80 \mathrm{~cm}$ & 0.81 & 0.91 & 1.16 & 1.06 & 0.88 & 0.93 & 0.94 & 0.95 \\
\hline Means (F) & 0.77 & 0.87 & 0.99 & 1.01 & 0.85 & 0.89 & 0.91 & --- \\
\hline \multicolumn{9}{|l|}{ LSD (0.05) } \\
\hline $\mathbf{S}$ & \multicolumn{8}{|c|}{0.04} \\
\hline $\mathbf{F}$ & \multicolumn{8}{|c|}{0.06} \\
\hline $\mathbf{S X F}$ & \multicolumn{8}{|c|}{0.03} \\
\hline
\end{tabular}

* PM1, PM2 and PM3 = Poultry manure at 10,15 and $20 \mathrm{~m} 3$ / fed., respectively. CM1, CM2 and CM3 = Cattle manure at 15, 25 and $35 \mathrm{m3}$ / fed., respectively. 
Table (7): Effect of spacing and organic fertilization treatments on the essential oil yield/ plant (ml) of Artemisia annua in 2008 and 2009 seasons.

\begin{tabular}{|c|c|c|c|c|c|c|c|c|}
\hline \multirow{3}{*}{$\begin{array}{l}\text { Plant } \\
\text { pacing } \\
(\mathrm{S})\end{array}$} & \multicolumn{7}{|c|}{ Essential oil yield / plant (ml) } & \multirow{3}{*}{$\begin{array}{c}\text { Means } \\
\text { (S) }\end{array}$} \\
\hline & \multicolumn{7}{|c|}{ Fertilization treatments $(\mathbf{F})^{*}$} & \\
\hline & Control & PM1 & PM2 & PM3 & CM1 & CM2 & CM3 & \\
\hline & \multicolumn{8}{|c|}{ First season (2008) } \\
\hline $60 \times 40 \mathrm{~cm}$ & 2.64 & 8.52 & 10.05 & 10.87 & 4.85 & 5.77 & 7.75 & 7.21 \\
\hline $60 \times 60 \mathrm{~cm}$ & 2.24 & 4.47 & 7.41 & 11.70 & 3.54 & 5.17 & 5.95 & 5.78 \\
\hline $60 \times 80 \mathrm{~cm}$ & 4.33 & 10.05 & 17.00 & 13.34 & 6.07 & 8.39 & 9.63 & 9.83 \\
\hline Means (F) & 3.07 & 7.68 & 11.48 & 11.97 & 4.82 & 6.44 & 7.78 & --- \\
\hline \multicolumn{9}{|l|}{ LSD (0.05) } \\
\hline $\mathbf{S}$ & \multicolumn{8}{|c|}{0.84} \\
\hline $\mathbf{F}$ & \multicolumn{8}{|c|}{0.68} \\
\hline \multirow[t]{2}{*}{$\mathbf{S} \mathbf{X} \mathbf{F}$} & \multicolumn{8}{|c|}{0.53} \\
\hline & \multicolumn{8}{|c|}{ Second season (2009) } \\
\hline $60 \times 40 \mathrm{~cm}$ & 2.61 & 8.61 & 10.27 & 11.73 & 5.00 & 6.12 & 7.83 & 7.45 \\
\hline $60 \times 60 \mathrm{~cm}$ & 2.39 & 4.54 & 7.60 & 11.76 & 3.83 & 5.51 & 6.13 & 5.96 \\
\hline $60 \times 80 \mathrm{~cm}$ & 4.37 & 9.98 & 18.15 & 13.89 & 6.37 & 8.36 & 9.67 & 10.11 \\
\hline Means (F) & 3.12 & 7.71 & 12.01 & 12.46 & 5.07 & 6.66 & 7.88 & --- \\
\hline \multicolumn{9}{|l|}{ LSD (0.05) } \\
\hline $\mathbf{S}$ & \multicolumn{8}{|c|}{2.50} \\
\hline $\mathbf{F}$ & \multicolumn{8}{|c|}{1.97} \\
\hline $\mathbf{S} \times \mathbf{F}$ & \multicolumn{8}{|c|}{3.19} \\
\hline
\end{tabular}

* PM1, PM2 and PM3 = Poultry manure at 10, 15 and $20 \mathrm{m3} /$ fed., respectively. CM1, CM2 and CM3 = Cattle manure at 15,25 and $35 \mathrm{m3} /$ fed., respectively 
Table (8): Effect of spacing and organic fertilization on the essential oil yield/fed. (kg) of Artemisia annua in 2008 and 2009 seasons.

\begin{tabular}{|c|c|c|c|c|c|c|c|c|}
\hline \multirow{3}{*}{$\begin{array}{l}\text { Plant } \\
\text { spacing } \\
\text { (S) }\end{array}$} & \multicolumn{7}{|c|}{ The essential oil yield / fed. (L) } & \multirow{3}{*}{$\begin{array}{c}\text { Means } \\
\text { (S) }\end{array}$} \\
\hline & \multicolumn{7}{|c|}{ Fertilization treatments $(\mathbf{F})^{*}$} & \\
\hline & Control & PM1 & PM2 & PM3 & CM1 & CM2 & CM3 & \\
\hline & \multicolumn{8}{|c|}{ First season (2008) } \\
\hline $60 \times 40 \mathrm{~cm}$ & 43.45 & 142.10 & 167.58 & 181.21 & 76.98 & 91.83 & 120.73 & 117.70 \\
\hline $60 \times 60 \mathrm{~cm}$ & 24.64 & 49.73 & 82.39 & 130.00 & 38.40 & 58.95 & 64.60 & 64.10 \\
\hline $60 \times 80 \mathrm{~cm}$ & 35.24 & 81.96 & 132.62 & 91.05 & 49.44 & 66.14 & 76.03 & 76.07 \\
\hline Means (F) & 34.44 & 91.26 & 127.53 & 134.09 & 54.94 & 72.30 & 87.12 & -- \\
\hline \multicolumn{9}{|l|}{ LSD (0.05) } \\
\hline $\mathbf{S}$ & \multicolumn{8}{|c|}{13.66} \\
\hline $\mathbf{F}$ & \multicolumn{8}{|c|}{15.51} \\
\hline $\mathbf{S X} \mathbf{F}$ & \multicolumn{8}{|c|}{11.65} \\
\hline & \multicolumn{8}{|c|}{ Second season (2009) } \\
\hline $60 \times 40 \mathrm{~cm}$ & 44.63 & 144.06 & 171.22 & 196.18 & 83.64 & 102.44 & 131.46 & 124.81 \\
\hline $60 \times 60 \mathrm{~cm}$ & 26.54 & 50.60 & 84.44 & 129.27 & 41.13 & 61.17 & 68.13 & 65.90 \\
\hline $60 \times 80 \mathrm{~cm}$ & 36.59 & 83.46 & 137.24 & 100.46 & 53.08 & 69.94 & 81.12 & 80.27 \\
\hline Means (F) & 35.92 & 92.71 & 130.97 & 141.97 & 59.28 & 77.85 & 93.57 & --- \\
\hline \multicolumn{9}{|l|}{ LSD $(0.05)$} \\
\hline $\mathbf{S}$ & \multicolumn{8}{|c|}{15.02} \\
\hline $\mathbf{F}$ & \multicolumn{8}{|c|}{16.64} \\
\hline $\mathbf{S} \times \mathbf{F}$ & \multicolumn{8}{|c|}{12.22} \\
\hline
\end{tabular}

* PM1, PM2 and PM3 = Poultry manure at 10, 15 and $20 \mathrm{~m} 3$ / fed., respectively. CM1, CM2 and CM3 = Cattle manure at 15, 25 and $35 \mathrm{m3} /$ fed., respectively. 


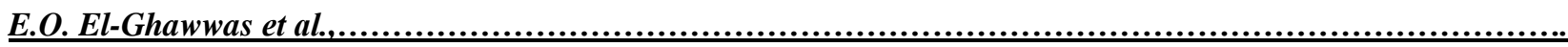

Table (9): Effect of spacing and organic fertilization on the components (\%) of the essential oil of Artemisia аппиа $\mathbf{L}$. in 2008 season.

\begin{tabular}{|c|c|c|c|c|c|c|c|c|}
\hline \multirow{2}{*}{$\begin{array}{l}\text { Plant } \\
\text { spacing } \\
\text { (S) }\end{array}$} & \multirow[b]{2}{*}{ Control } & \multicolumn{5}{|c|}{$\frac{\text { The components }(\%) \text { of the essential oil }}{\text { Fertilization treatments }(\mathrm{F})^{*}}$} & \multirow[b]{2}{*}{ CM3 } & \multirow[t]{2}{*}{$\begin{array}{l}\text { Means } \\
\quad(\mathbf{S})\end{array}$} \\
\hline & & PM1 & PM2 & PM3 & CM1 & CM2 & & \\
\hline & & & & $\alpha$ - Thujene & & & & \\
\hline $60 \times 40 \mathrm{~cm}$ & 0.683 & 0.653 & 0.500 & 0.562 & 0.778 & 0.767 & 1.131 & 0.724 \\
\hline $60 \times 60 \mathrm{~cm}$ & 1.043 & 1.574 & 1.310 & 1.075 & 1.484 & 1.024 & 0.978 & 1.212 \\
\hline $60 \times 80 \mathrm{~cm}$ & 2.683 & 0.834 & 0.722 & 0.938 & 1.810 & 0.606 & 0.661 & 1.179 \\
\hline \multirow[t]{2}{*}{ Means (F) } & 1.469 & 1.020 & 0.844 & 0.858 & 1.357 & 0.799 & 0.923 & 1.038 \\
\hline & & & & $\alpha$ - Pinene & & & & \\
\hline $60 \times 40 \mathrm{~cm}$ & 1.079 & 0.821 & 1.087 & 2.034 & 1.279 & 1.607 & 2.421 & 1.475 \\
\hline $60 \times 60 \mathrm{~cm}$ & 2.306 & 2.341 & 3.101 & 1.971 & 1.824 & 1.486 & 2.075 & 2.157 \\
\hline $60 \times 80 \mathrm{~cm}$ & 2.893 & 1.360 & 1.142 & 1.089 & 2.014 & 1.557 & 1.697 & 1.678 \\
\hline \multirow[t]{2}{*}{ Means (F) } & 2.092 & 1.507 & 1.776 & 1.698 & 1.705 & 1.550 & 2.064 & 1.770 \\
\hline & & & & Camphene & & & & \\
\hline $60 \times 40 \mathrm{~cm}$ & 4.242 & 2.336 & 2.045 & 1.275 & 3.540 & 1.865 & 3.229 & 2.647 \\
\hline $60 \times 60 \mathrm{~cm}$ & 4.731 & 6.176 & 1.594 & 4.155 & 3.555 & 2.145 & 5.969 & 4.046 \\
\hline $60 \times 80 \mathrm{~cm}$ & 3.461 & 1.536 & 2.893 & 3.870 & 2.556 & 1.475 & 4.380 & 2.881 \\
\hline \multirow[t]{2}{*}{ Means (F) } & 4.144 & 3.349 & 2.177 & 3.100 & 3.217 & 1.828 & 4.526 & 3.191 \\
\hline & & & & $\beta$ - pinene & & & & \\
\hline $60 \times 40 \mathrm{~cm}$ & 4.713 & 2.575 & 5.737 & 1.986 & 1.934 & 4.501 & 1.939 & 3.340 \\
\hline $60 \times 60 \mathrm{~cm}$ & 1.807 & 8.149 & 3.049 & 2.616 & 7.917 & 4.760 & 4.915 & 4.744 \\
\hline $60 \times 80 \mathrm{~cm}$ & 3.688 & 3.004 & 2.524 & 5.564 & 2.660 & 6.579 & 2.177 & 3.742 \\
\hline \multirow[t]{2}{*}{ Means (F) } & 3.402 & 4.576 & 3.770 & 3.388 & 4.170 & 5.280 & 3.010 & 3.942 \\
\hline & & & & $\begin{array}{c}\alpha- \\
\text { Terpinene }\end{array}$ & & & & \\
\hline $60 \times 40 \mathrm{~cm}$ & 2.253 & 2.618 & 3.820 & 2.089 & 3.872 & 1.984 & 1.707 & 2.620 \\
\hline $60 \times 60 \mathrm{~cm}$ & 2.827 & 1.910 & 1.451 & 1.719 & 0.903 & 1.457 & 1.735 & 1.714 \\
\hline $60 \times 80 \mathrm{~cm}$ & 2.381 & 1.179 & 1.348 & 1.569 & 3.095 & 1.248 & 0.869 & 1.669 \\
\hline \multirow[t]{2}{*}{ Means (F) } & 2.487 & 1.902 & 2.206 & 1.792 & 2.623 & 1.563 & 1.437 & 2.001 \\
\hline & & & & 1,8 Cineol & & & & \\
\hline $60 \times 40 \mathrm{~cm}$ & 16.524 & 7.692 & 9.858 & 9.052 & 14.422 & 11.941 & 8.938 & 11.203 \\
\hline $60 \times 60 \mathrm{~cm}$ & 10.483 & 14.060 & 10.378 & 11.984 & 12.035 & 14.447 & 8.025 & 11.630 \\
\hline $60 \times 80 \mathrm{~cm}$ & 10.747 & 14.085 & 9.842 & 10.955 & 14.109 & 10.394 & 9.654 & 11.398 \\
\hline \multirow[t]{2}{*}{ Means (F) } & 12.584 & 11.945 & 10.026 & 10.663 & 13.522 & 12.260 & 8.872 & 11.410 \\
\hline & \multicolumn{7}{|c|}{ Artemisia keton } & \\
\hline $60 \times 40 \mathrm{~cm}$ & 21.525 & 35.764 & 36.319 & 40.591 & 30.440 & 33.069 & 36.889 & 33.513 \\
\hline $60 \times 60 \mathrm{~cm}$ & 19.723 & 24.847 & 30.788 & 39.036 & 21.121 & 30.833 & 36.804 & 29.021 \\
\hline $60 \times 80 \mathrm{~cm}$ & 29.432 & 38.390 & 44.113 & 43.326 & 33.729 & 39.556 & 40.616 & 38.451 \\
\hline Means (F) & 23.560 & 33.000 & 37.073 & 40.984 & 28.430 & 34.486 & 38.103 & 33.662 \\
\hline
\end{tabular}

\section{Continued}


Effect of organic fertilization and plant spacing on the...

Table 9:Continued

\begin{tabular}{|c|c|c|c|c|c|c|c|c|}
\hline \multirow{2}{*}{$\begin{array}{l}\text { Plant } \\
\text { spacing } \\
\text { (S) }\end{array}$} & \multicolumn{7}{|c|}{$\frac{\text { The components }(\%) \text { of the essential oil }}{\text { Fertilization treatments }(\mathbf{F})^{*}}$} & \multirow{2}{*}{$\begin{array}{l}\text { Means } \\
\quad(\mathbf{S})\end{array}$} \\
\hline & Control & PM1 & PM2 & PM3 & CM1 & CM2 & CM3 & \\
\hline \multicolumn{9}{|c|}{ Terpinolene } \\
\hline $60 \times 40 \mathrm{~cm}$ & 4.363 & 4.034 & 3.504 & 2.592 & 5.368 & 3.145 & 3.415 & 3.774 \\
\hline $60 \times 60 \mathrm{~cm}$ & 5.211 & 3.175 & 3.638 & 2.866 & 3.037 & 3.923 & 2.528 & 3.482 \\
\hline $60 \times 80 \mathrm{~cm}$ & 6.962 & 2.820 & 3.458 & 3.035 & 3.893 & 1.939 & 3.467 & 3.653 \\
\hline Means (F) & 5.512 & 3.343 & 3.533 & 2.831 & 4.099 & 3.002 & 3.136 & 3.636 \\
\hline \multicolumn{9}{|c|}{ Camphor } \\
\hline $60 \times 40 \mathrm{~cm}$ & 13.850 & 10.840 & 12.896 & 10.709 & 11.650 & 20.460 & 23.392 & 14.828 \\
\hline $60 \times 60 \mathrm{~cm}$ & 23.192 & 15.495 & 18.115 & 16.472 & 14.624 & 22.643 & 18.273 & 18.431 \\
\hline $60 \times 80 \mathrm{~cm}$ & 12.106 & 12.545 & 10.118 & 9.963 & 13.416 & 17.046 & 15.837 & 13.004 \\
\hline Means (F) & 16.450 & 12.960 & 13.709 & 12.381 & 13.230 & 20.049 & 19.167 & 15.421 \\
\hline \multicolumn{9}{|c|}{ Borneol } \\
\hline $60 \times 40 \mathrm{~cm}$ & 2.825 & 2.294 & 1.546 & 5.558 & 5.097 & 3.084 & 2.497 & 3.271 \\
\hline $60 \times 60 \mathrm{~cm}$ & 3.161 & 2.456 & 7.729 & 1.522 & 3.770 & 1.827 & 2.122 & 3.226 \\
\hline $60 \times 80 \mathrm{~cm}$ & 1.414 & 2.053 & 3.185 & 2.242 & 3.154 & 2.119 & 4.254 & 2.631 \\
\hline Means (F) & 2.466 & 2.2676 & 4.153 & 3.107 & 4.007 & 2.343 & 2.957 & 3.043 \\
\hline \multicolumn{9}{|c|}{ Eugenol } \\
\hline $60 \times 40 \mathrm{~cm}$ & 3.063 & 2.805 & 2.022 & 1.832 & 2.294 & 1.531 & 1.145 & 2.098 \\
\hline $60 \times 60 \mathrm{~cm}$ & 2.183 & 1.767 & 1.904 & 1.463 & 1.638 & 1.227 & 1.852 & 1.719 \\
\hline $60 \times 80 \mathrm{~cm}$ & 2.090 & 2.890 & 2.336 & 1.822 & 1.166 & 1.549 & 1.499 & 1.907 \\
\hline Means (F) & 2.445 & 2.487 & 2.087 & 1.705 & 1.699 & 1.435 & 1.498 & 1.908 \\
\hline \multicolumn{9}{|c|}{ B Caryophellene } \\
\hline $60 \times 40 \mathrm{~cm}$ & 3.699 & 4.345 & 5.600 & 3.872 & 6.040 & 3.278 & 2.892 & 4.246 \\
\hline $60 \times 60 \mathrm{~cm}$ & 4.862 & 4.826 & 5.035 & 4.786 & 3.600 & 4.129 & 3.815 & 4.436 \\
\hline $60 \times 80 \mathrm{~cm}$ & 6.232 & 4.690 & 3.646 & 5.015 & 4.189 & 3.596 & 3.989 & 4.479 \\
\hline Means (F) & 4.931 & 4.620 & 4.760 & 4.557 & 4.609 & 3.667 & 3.565 & 4.387 \\
\hline \multicolumn{9}{|c|}{ Unknown Components } \\
\hline $60 \times 40 \mathrm{~cm}$ & 21.181 & 23.223 & 15.066 & 17.848 & 13.286 & 12.768 & 10.405 & 16.253 \\
\hline $60 \times 60 \mathrm{~cm}$ & 18.471 & 13.224 & 14.908 & 10.335 & 24.492 & 10.099 & 10.909 & 14.634 \\
\hline $60 \times 80 \mathrm{~cm}$ & 15.911 & 14.614 & 14.673 & 10.612 & 14.209 & 12.336 & 10.900 & 13.322 \\
\hline Means (F) & 18.521 & 17.020 & 14.882 & 12.931 & 17.329 & 11.734 & $\mathbf{1 0 . 7 3 8}$ & 14.736 \\
\hline
\end{tabular}

* PM1, PM2 and PM3 = Poultry manure at 10,15 and $20 \mathrm{~m} 3$ / fed., respectively.

CM1, CM2 and CM3 = Cattle manure at 15, 25 and $35 \mathrm{m3}$ / fed., respectively.

Table (10): Effect of spacing and organic fertilization treatments on the rtemisinin content $(\%)$ in the dry leaves of Artemisia апnиa in 2008 season.

\begin{tabular}{|c|c|c|c|c|}
\hline \multirow{2}{*}{$\begin{array}{c}\text { Plant spacing } \\
(S)\end{array}$} & \multicolumn{3}{|c|}{ Artemisinin content (\% of dry leaves) } & \multirow{2}{*}{ Means (S) } \\
\cline { 2 - 4 } & \multicolumn{3}{|c|}{ Fertilization treatments (F)* } & \\
\cline { 2 - 4 } & Control & PM3 & CM3 & 1.75 \\
\hline $60 \times 40 \mathrm{~cm}$ & 1.09 & 2.26 & 1.91 & 2.29 \\
\hline $60 \times 60 \mathrm{~cm}$ & 1.18 & 3.83 & 1.88 & 2.51 \\
\hline $60 \times 80 \mathrm{~cm}$ & 1.39 & 3.84 & 2.31 & \\
\hline Means (F) & 1.22 & 3.31 & 2.03 & -- \\
\hline
\end{tabular}

PM3: poultry manure at $20 \mathrm{m3}$ / fed. $\quad$ CM3: cattle manure at $35 \mathrm{~m} 3$ / fed. 
increasing the oil yield/fed. when it was applied at the rates of 15 or $20 \mathrm{~m}^{3}$. The above results are in agreement with the findings of El-Ghadban (1998) on Mentha viridis and Mohsen (2002) on Ocimum basilicum L. cv."Grand Vert".

It is also evident from the results in Table (8) that the interaction between the effects of plant spacing and organic fertilization on the oil yield/fed. was significant. In both seasons, the plants planted at the narrowest spacing $(60 \times 40$ $\mathrm{cm}$ ) and fertilized with $\mathrm{PM}$ at $20 \mathrm{~m}^{3} / \mathrm{fed}$. gave the highest oil yield/fed.

\subsection{Essential oil components}

Chromatographic analysis of oil samples extracted from Sweet Annie plants in the first season (Table 9) show that artemisia keton was the most important essential oil component (with contents of 19.723-44.113\%), followed by camphor (with contents of 9.963-23.392\%), then 1,8 Cineol (with contents of 7.692-16.524\%). Also, the data in Table (6) show that plant spacing had a considerable effect on the artemisia keton content. The maximum mean content $(38.451 \%)$ was obtained with a spacing of $60 \times 80 \mathrm{~cm}$, followed by $60 \times 40 \mathrm{~cm}$ (with a value 33.513\%), then $60 \times 60 \mathrm{~cm}$ (with a value of 29.021\%). The data in Table (9) also show that the plants fertilized with PM at $20 \mathrm{~m}^{3} / \mathrm{fed}$. had the highest artemisia keton content $(40.984 \%)$, followed by the plants receiving $\mathrm{PM}$ at $15 \mathrm{~m}^{3} / \mathrm{fed}$. (with an artemisia keton content of $37.073 \%$ ). Plants grown at a spacing of $60 \times 80 \mathrm{~cm}$ and fertilized with PM at $15 \mathrm{~m}^{3} / \mathrm{fed}$. had a higher artemisia keton content $(44.113 \%)$ than plants receiving any other treatment combination.

\section{Artemsinin content in the leaves (\%)}

It can be seen from the data in Table (10) that the artemisinin content in the leaves of Artemisia annua was affected by the plant spacing treatments. The widest spacing $(60 \times 80 \mathrm{~cm})$ gave the highest mean artemisinin content (2.51\%). Moreover, decreasing the plant spacing caused a steady reduction in the artemisinin content. Similar increases in the artemisinin content as a result of wide plant spacing have been reported by Galanopoulou et al. (2002) and Mert et al. (2002) on Artemisia annua L.

The data presented in Table (10) also show that organic fertilization (using CM or PM) caused a marked increase in the artemisinin content in Artemisia апnиa leaves, compared to that of the control plants. The highest mean artemisinin content $(3.31 \%)$ was obtained in plants fertilized with poultry manure at $20 \mathrm{~m}^{3} / \mathrm{fed}$, whereas plants fertilized with cattle manure at $35 \mathrm{~m}^{3} / \mathrm{fed}$. had an artemisinin content of $2.03 \%$.

Regarding the interaction between the effects of plant spacing and organic fertilization on the artemisinin content, the data presented in Table (10) show that considerable differences were recorded between the artemisinin contents of plants receiving the various combination of these two factors. The highest artemisinin content (3.84\%) was obtained in the leaves of plants grown at the widest spacing $(60 \times 80 \mathrm{~cm})$ and supplied with the highest PM rate $\left(20 \mathrm{~m}^{3} / \mathrm{fed}\right.$.), followed by the plants receiving the same PM rate $\left(20 \mathrm{~m}^{3} /\right.$ fed.), but combined with the medium plant spacing $(60 \times 60 \mathrm{~cm})$, which gave an artemisinin content of $3.83 \%$.

From the aforementioned results, it can be concluded that the plants grown at the widest spacing $(60 \times 80 \mathrm{~cm})$ and fertilized with PM at 15 $\mathrm{m}^{3} / \mathrm{fed}$. gave the highest fresh and dry herb yields/plant, as well as the highest essential oil percentage, the highest oil yield/plant, and the highest content of artemisia keton (the main oil component) in the oil. However, growing the plants at the narrowest spacing $(60 \times 40 \mathrm{~cm})$ considerably increased plant density (the number of plants/fed.). Consequently, plants grown at this spacing $(60 \times 40 \mathrm{~cm})$ and fertilized with PM at 20 $\mathrm{m}^{3} / \mathrm{fed}$. gave the highest fresh and dry herb yields/fed., as well as the highest essential oil yield/fed.

\section{REFERENCES}

Ahmed E. T. (1997). Influence of plant distance and some phosphorus fertilization sources on black cumin (Nigella sativa L.) plants. Assiut J. of Agric. Sci., 28(2):78-89.

Ahmed E. T. (1986). Effect of some agricultural treatments on growth, flowering and oil content of Achillea spp. M. Sc. Thesis, Fac. Agric., Minia Univ.

Badi H.N., Yazdani D., Ali S.M. and Nazari F. (2004). Effects of spacing and harvesting time on herbage yield and quality/quantity of oil in the thyme, Thymus vulgaris $\mathrm{L}$. Industrial Crops and Products, 19 (3): 231236.

British Pharmacopoeia (1963). Determination of Volatile Oils in Drugs. The Pharmaceutical Press, 17 Bloomsbury Square, London, WC1.

El-Gendy S. A., Hosni A. M., Ahmed S. S. and Hossein A.F. (2010). Determination of the vegetative and reproductive characteristics 
of valerian (Valeriana officinalis L.) under sowing dates and planting densities at Iran. J. Medic. Plants Res., 4(10): 857-861.

El-Gendy S. A., Hosni A. M., Ahmed S. S. and Omer, E. A. (2001b). Variation in herbage yield, essential oil yield and oil composition of sweet basil (Ocimum basilicum L. var."Grand Vert") grown organically in a newly reclaimed land in Egypt. Arab Universities Journal of Agricultural Sciences, 9(2): 915-933. (C.f. Hort. Abst., 72: 5924).

El-Gendy S. A., Hosni A. M., Ahmed S. S. and Sabri R. M. (2001a). Sweet basil (Ocimum basilicum L.) productivity under different organic fertilization and inter-plant spacing levels in newly reclaimed land in Egypt. Annals of Agricultural Science Cairo, 46 (1): 319-338.

El-Ghadban E. A. E. (1998). Effect of some organic and inorganic fertilizers on growth, oil yield and chemical composition of spearmint and majoram plants. Ph.D. Thesis, Fac. Agric., Cairo Univ., Egypt, 232 pp.

El-Shaer S. T. (1989) Effect of plant spacing and growth regulators on growth, seed yield and volatile oil of fennal plant. M. Sc. Thesis, Fac. Agric., Zagazig Univ.

El-Tantawy A., Salim S. M. and Hanafy M. S. (1992). Effect of nitrogen fertilization and row spacing on the growth, dry fruit yield and essential oil of fennel (Foeniculum vulgare Mill.) plants. Egypt. J. Appi. Sci., 7(12): 373-387.

Galanopoulou S. S., Papanastasion P., Pappas A. and Pappas X. (2002). Cultivation condition in Greece producing Artemisia annua L. plants with a high yield of antimalarial drug artemisinin. Rivista Italiana EPPOS, 1(33): $35-42$.

Hassan R. I. (2008). Effect of some organic fertilization on the growth, yield and chemical constituents of thyme plant. M.Sc. Thesis, Fac. Agric., Ain Shams Univ., Egypt, 176 pp.

Jacoub R. W. (1999). Effect of some organic and non-organic fertilizers on growth, oil yield and chemical composition of Ocimum basilicum L. and Thymus vulgaris L. plants. Ph.D. Thesis, Fac. Agric., Cairo Univ., Egypt, 226 pp.

Kalyan S., Ram P., Singh J. P., Singh K. and Ram, P. (1989). Effect of nitrogen and inter row spacings on herb and oil yield of transplanted Japanese mint (Mentha arvensis L.). Annals of Agricultural Research, 10 (3): 258-261.

Little T.M. and Hills F.J. (1978). Agricultural Experimentation - Design and Analysis. John Wiley and Sons, Inc., pp. 53-60, 6365.

Mert A., Krc S. and Ayanoglu F. (2002). The effect of different plant densities on yield, yield components and quality of Artemisia annua L. ecotypes. Journal of Herbs, Spices and Medicinal Plants, 9(4): 413-418.

Mohsen M.M.A. (2002). Sweet basil herb and oil production as affected by chemical and organic fertilization. M.Sc. Thesis, Fac. Agric., Cairo Univ., Egypt, 247 pp.

Obi I.U. (1991). Maize, its agronomy, diseases, pests and food values. Optional Computer Solutions Ltd., Enugu, Pp 207.

Peng C.A., Ferreira J.F.S., and Wood A. J. (2006). Direct analysis of artemisinin from Artemisia annua L. using high-performance liquid chromatography with evaporative light scattering detector, and gas chromatography with flame ionization detector. Journal of Chromatography, A, 1133: 254-258

Ram P., Patra N. K., Singh H. B., Singh H. P., Muni R., Birendra K. and Sushil, K. (1998). Effect of planting date and spacing on oil yield and major yield components of Tagetes minuta. Journal Medic. Arom. Plant Sci., 20(3): 742-745.

Refai K., A. Mansour R. M., Bosila H. A. and Farouh R. A. (1991). Effect of planting dates and spacings on essential oil percentage in Ruta graveolens L. plant. Zagazig J. Agric. Res., 18(6): 2123-2132.

Salim E. M. A. L. (2006). Effect of chemical, organic fertilizers and spraying with active dry yeast on growth, oil production and plant constituents of sage (Salvia officinalis L.) plants. M.Sc. Thesis, Fac. Agric., Cairo Univ., Egypt, 236 pp.

Shalaby A. S. and Razin, A. M. (1992). Dense cultivation and fertilization for higher yield of thyme (Thymus vulgaris). Journal of Agronomy and Crop Science, 168 (4): 243248.

Shalaby A. S., Khattab M. D., El-Gamassy A. and El-Gamassy K. (1993). Cultivation of Melissa officinalis in Egypt. Effects of fertilization, spacing and planting season. Acta-Horticulturae, 331: 115-120.

Simon J.E. and Quinn J. (1988). Characterization 
of essential oil of parsley. J Agric. Food Chem., 36: 467-472.

Vieira M. C., Heredia Z., Nestor A. and Ramos M. B. (2002). Biomass yield of Mentha villosa and Metha longifolia as a function of semi-decomposed chicken manure and harvest time. Rivista Brasileira de Plantas
Medicinais, 4(2): 25-29.

Zhong Guoyue (1998). Investigation on ecological environment and quantitative analysis of artemisinin of sweet wormwood (Artemisia annua). Chinese Traditional and Herbal Drugs (29): 264-267.

\section{تأثير التسميد العضوى ومسافات الزراعة على الثمو وإنتاج الزيت \\ ومحتوى الأرتيميسينين فى نبات الأرتيميسا (Artemisia annua, L.)}

إعثماد عثمان الغواص* صفية حمدى الحنفى ـ حازم عبد الجليل منصور سارة ناجى عبد الخالق*

$$
\text { *قم بحوث النباتات الطبية و العطرية- معهد بحوث الزينة ـ كلية الزراعة - جامعة القاهرة البساتين- مركز البحوث الزر اعية ـ الجيزة }
$$

\section{ملخص}

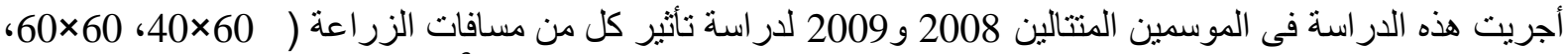

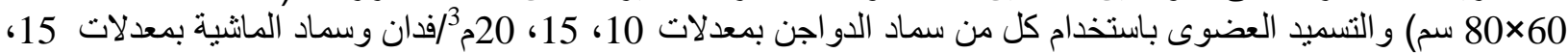

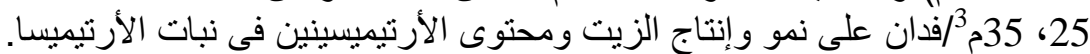

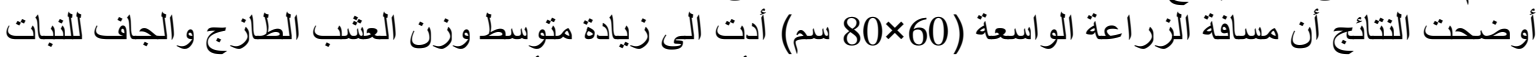

و النسبة المئوية للزيت ومحصول الزيت للنبات وزيادة محتوى الأرتيميسينين فى أوراق النبات، وكانت المسافة

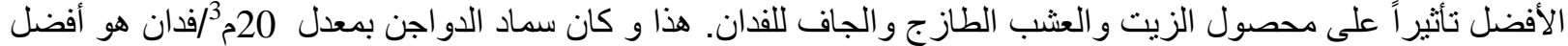

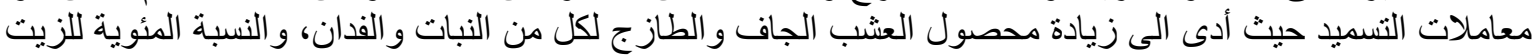

ومحصول الزيت للنبات ومحتوى الأرتيميسينين فى أوراق النبات. أدى الجمع بين أوسع مسافات زر زاعة ( 60 ( 60 × 80 سم)

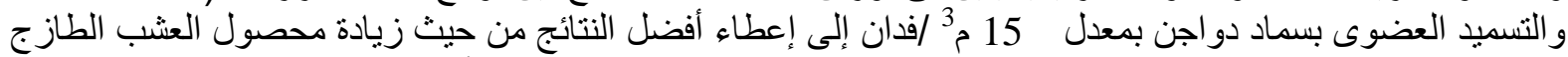

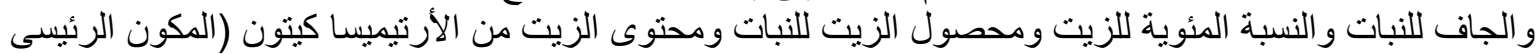

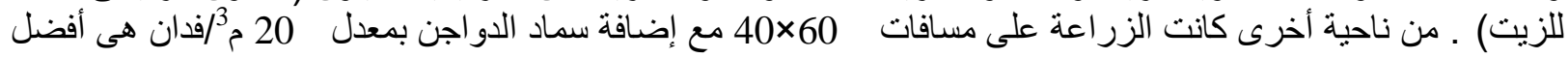

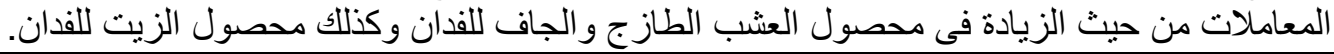
المجلة العلمية لكلية الزراعة - جامعة القاهرة - المجلد (62) العدد الثالث ( يوليو ): 362-377. 